\title{
DIGITAL VEHICLE SECURITY PLATFORM PROPOSAL
}

\author{
Paulo R. T. Oliveira ${ }^{a}$,Herman Augusto Lepikson ${ }^{b}$ \\ a Ford Motor Company, Brazil,

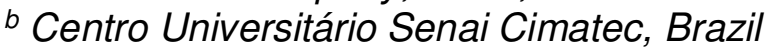

\begin{abstract}
Security is one of the most important need of the human being and the actual reality in Brazil, where the number of express kidnappings, vehicles thefts is increasing year over year drives the society to not feel safe enough. As a result, the security business is presenting a continuous growth in the last years and demanding new solutions. Considering this scenario, this article aims to propose a vehicle security platform, combining existing and upcoming technologies, to identify situations where the vehicle can be an active agent on people's security.
\end{abstract}

Keywords: Security; Vehicle; Digital; Platform.

\section{PROPOSTA DE UMA PLATAFORMA DE SEGURANÇA DIGITAL VEÍCULAR}

Resumo: Segurança é uma das necessidades básicas do ser humano e a realidade atual no Brasil, onde o número de sequêstros-relâmpagos e roubo de veículos vem crescendo ano após ano está levando a um sentimento de insegurança na sociedade. Como resultado, o mercado ligado a segurança vem crescendo nos últimos anos e demandando novas soluções. Considerando esse cenário, esse artigo tem como objetivo propor uma plataforma de segurança digital veícular, combinando tecnologias existentes e novas, para identificar situações onde o veículo pode ser um agente ativo da segurança das pessoas.

Palavras-chave: Segurança; Veícular; Digital; Plataforma. 


\section{INTRODUCTION}

All human being has needs, motivations and aspirations which affects their day by day activities and decisions. To better understand these human needs and determine how they relate to each other, Abraham Harold Maslow (1908 - 1970), psychologist and MIT researcher, develop a theory called Maslow's Hierarchy of Needs or Maslow's Pyramid.

Figure 1. Maslow's Pyramid

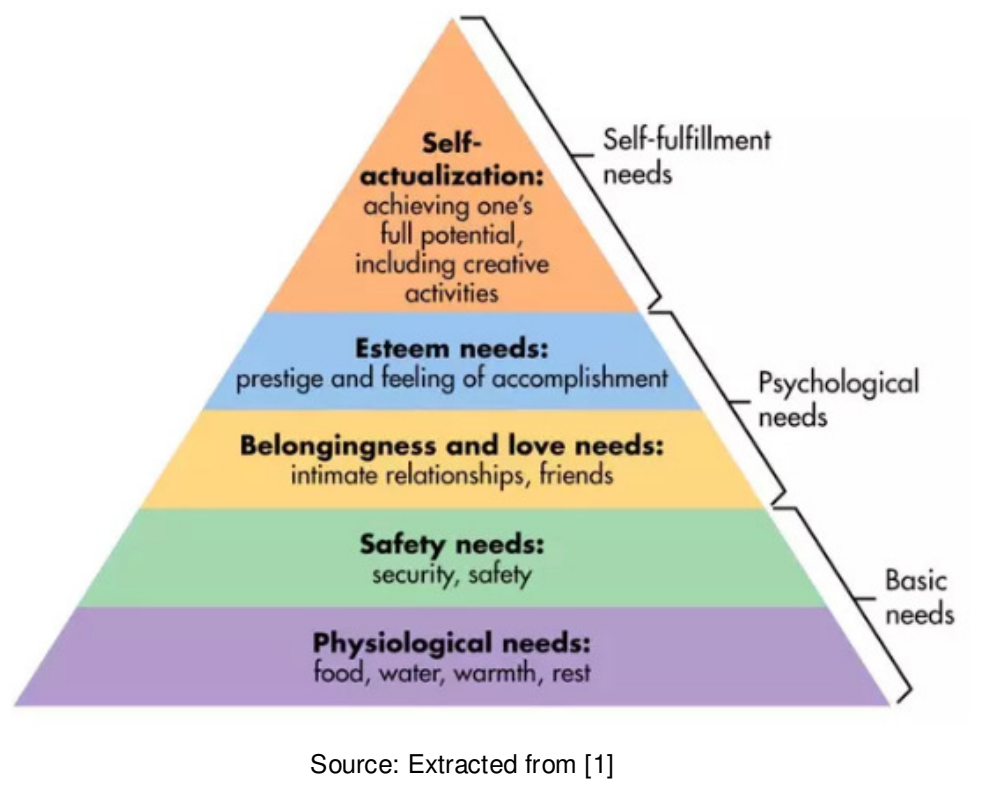

According to Maslow, the individuals to go to the upper levels in the pyramid, first must satisfy he needs in the lower levels to them think about the next ones, it means, after getting his physiological needs met, the most important thing for the individual is security and safety [2].

The definition of security according to the Oxford American Dictionary is: 1. secure condition or feeling; and Secure means: 1. Untroubled by danger or fear [3].

Considering these definitions, the individuals in Brazil are getting their "secure condition" and the "untroubled by danger or fear" feeling reduced year over year due to the reality in the country caused by grown urban violence indicators. The situation is so alarming to a point that Brazil reached in 2014 a metric of 1 vehicle stolen per minute [4]. Also, according to the Social Progress imperative [5], the country was ranked in 2018 as the $11^{\circ}$ country less safe in the world. Another indicator is the increasing number of express kidnappings on the states like Pernambuco with a growth of 41\% in 2018 [6] and in São Paulo with 30\% increase in 2017 [7] and 1 case per day registered in 2018 [8].

In this context, considering the importance of security for the human, following Maslow's pyramid theory, and the security situation in Brazil, indicates the individuals will always be looking for alternatives and any solution in this field will be relevant for human well-being. 


\subsection{Vehicle Security}

Today, vehicles are designed to be a safe place for the occupants and pedestrians in case of collision. They can also have features to prevent or avoid collisions. The vehicle safety performance is getting a lot of the customer attention and it is starting to be part of the reasons to buy a vehicle. However, even with all technology in place, there are still situations where the lack of security in the cities can make the vehicle occupants vulnerable without any chance to protect from this condition.

In situations like an express kidnapping and vehicle theft, the driver normally does not have any chance to react without put himself at a bigger risk, therefore these are the moments where the vehicle could have an extra role on the security. This article intent is to propose a digital platform where the vehicle will have artificial intelligence to identify these risk conditions, take actions and decisions to help the customers and create a safer environment.

\subsection{Technologies}

The technical base for the platform is combine existing and new technologies that are not necessarily being used in the automotive industry nor for security purpose.

Face, object and voice recognition are technologies available with extensive usage, including security, which the usage can be extended for the automotive industry [9].

Another technology to be explored is the emotions recognition. Most of the articles indicates its usage on the medical area, focused to identify the pain levels on people with communication difficulties [10] [11].

A digital platform needs to be connected and, in this case, it will not be different, it means the vehicle will need to be connected to external data and it will also need to be accessed by outside. Based on that, this study assumes availability of $5 \mathrm{G}$ internet connection, IOT and smart cities.

Considering the amount of data that will be generated in the vehicle and its interactions with the external world, the platform will require a big data for processing to support the vehicle artificial intelligence.

\section{METHODOLOGY}

To develop the proposal for digital vehicle security platform it is necessary to define the situations where the platform will actuate. By defining how the platform will work, it will help to determine what are the required content in the vehicle and technology to support the project.

The platform scope will be limited to work on express kidnapping, vehicle theft, stolen vehicle and cargo recovery, fleet control and thief identification. 
Once the platform scope is defined, the next step will be to create a framework to understand the interactions between the vehicle and the required technology to delivery the platform functionality. This is an important step for the project because it will be the basis to define the required hardware in vehicle and the platform feasibility due to technology availability.

After the framework hardware and technology definition, it will be possible the establish the platform operating mode concept based on the data generated in the vehicle and how it will help on the necessary knowledge to assure customer security.

\section{RESULTS AND DISCUSSION}

The series of data generated inside the vehicle, like face, emotion, voice and object recognition in conjunction with a connected vehicle in a smart environment will generate enough data to support an artificial intelligence development in the vehicle to take actions and decisions on behalf of the customer in risk situations.

Figure 1. Digital Vehicle Security Platform Framework

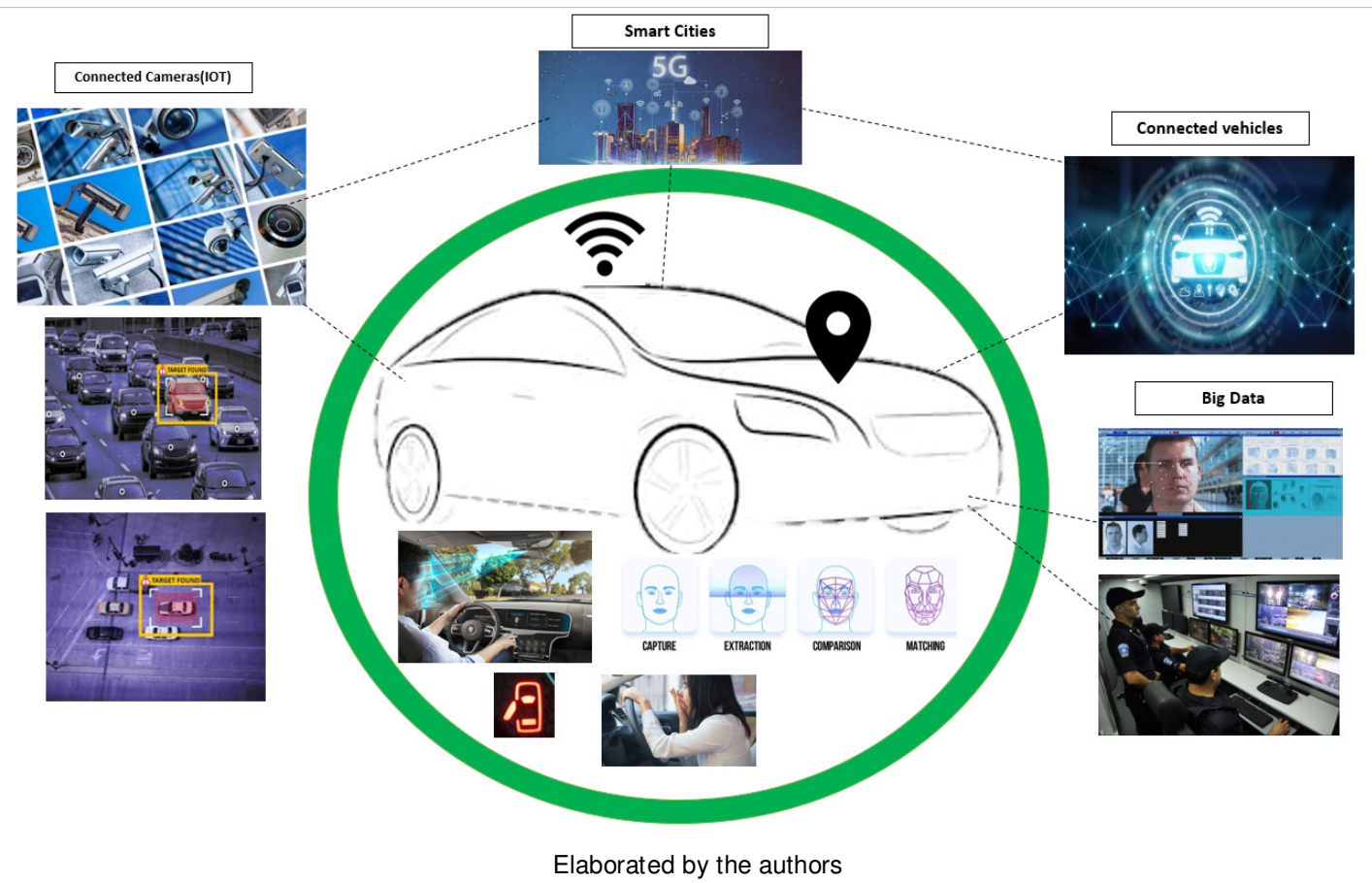

Based on the interfaces and interactions identified the required hardware and software in the vehicles are described below (Tables 1 and 2): 
Table 1. Platform Hardware

\begin{tabular}{|c|c|c|c|}
\hline Hardware & Function & $\begin{array}{c}\text { Existing } \\
\text { Technology? }\end{array}$ & $\begin{array}{c}\text { Prior Usage } \\
\text { in Vehicles? }\end{array}$ \\
\hline Camera & $\begin{array}{c}\text { Image capture for Face } \\
\text { and emotions recognition }\end{array}$ & $\mathrm{Y}$ & $\mathrm{N}$ \\
\hline Module & $\begin{array}{c}\text { Image and sound } \\
\text { processing and IA }\end{array}$ & $\mathrm{Y}$ & $\mathrm{N}$ \\
\hline Modem & Connect the vehicle & $\mathrm{Y}$ & $\mathrm{Y}$ \\
\hline Microphone & $\begin{array}{c}\text { Audio capture for voice } \\
\text { recognition }\end{array}$ & $\mathrm{Y}$ & $\mathrm{Y}$ \\
\hline
\end{tabular}

Elaborated by the authors

Table 2. Platform Software

\begin{tabular}{|l|c|c|}
\hline \multicolumn{1}{|c|}{ Software } & Existing Technology? & TRL \\
\hline Cellular App & N & 3 \\
\hline Face recognition & Y & 8 \\
\hline Emotion recognition & Y & 3 \\
\hline Audio Recognition & 9 & 9 \\
\hline Smart city Connection & N & 2 \\
\hline Al development & Y & 3 \\
\hline
\end{tabular}

Elaborated by the authors

The framework analysis allows the development of the platform operating mode concept as indicated in the Table 3 . The assumption is to have all the image and audio being processed locally in the vehicle, in a specific module to allow a faster response from the system, specially on the Risk identification steps. Processing the data outside the vehicle would drive to an excessive data being exchanged with the car, in most of the cases for no reason, but mainly to bring a risk of not complete the analysis due to lack of internet.

The modem will be key in for the platform. It will be used to connect the Al module to ask for help and provide support to the police during and after the risk situation. It will also be the link between the owner and the vehicle in case of stolen vehicle and fleet control to stop the vehicle or allow the usage.

The modem will also be connected to a cellular phone app, providing a warning message in case of emergency and allow communication with the vehicle. This communication can be passive, where the police or the owner can monitor what is happening in the vehicle or active allowing communication with who is in the vehicle or even stopping it. 
Table 3. Platform Operating Mode Concept

\begin{tabular}{|c|c|c|c|c|c|}
\hline & & 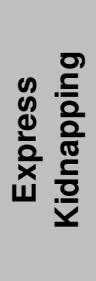 & $\begin{array}{l}\frac{0}{0} \\
\frac{0}{0} \\
\stackrel{5}{\frac{c}{0}} \\
\frac{c}{0} \\
\frac{0}{0}\end{array}$ & 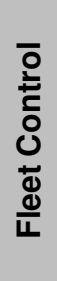 & 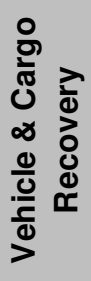 \\
\hline \multirow{6}{*}{ 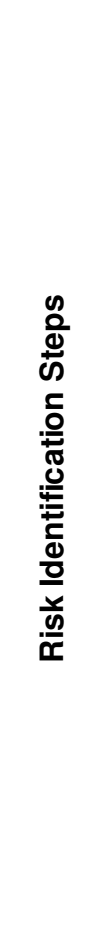 } & $\begin{array}{l}\text { Vehicle monitoring vehicle data (Door } \\
\text { Ajar, speed...) }\end{array}$ & $\mathbf{x}$ & $\mathbf{X}$ & $\mathbf{X}$ & $\mathbf{X}$ \\
\hline & $\begin{array}{l}\text { System activates camera and } \\
\text { microphone according to the data } \\
\text { monitored }\end{array}$ & $\mathbf{X}$ & $\mathbf{X}$ & $\mathbf{X}$ & $\mathbf{X}$ \\
\hline & $\begin{array}{l}\text { Vehicle Al will analyze images for face } \\
\text { recognition, emotion identification (i.e. } \\
\text { Panic, tension, fear...), objects } \\
\text { recognition (i.e. Gun, knife...) and } \\
\text { audio analysis (voice tone and key } \\
\text { words). }\end{array}$ & $\mathbf{x}$ & $\mathbf{X}$ & $\mathbf{X}$ & $\mathbf{X}$ \\
\hline & $\begin{array}{l}\text { Platform will cross check the captured } \\
\text { images with the police database, } \\
\text { driver social media photos to try to } \\
\text { identify the people in the car. }\end{array}$ & $\mathbf{X}$ & $\mathbf{X}$ & $\mathbf{X}$ & $\mathbf{X}$ \\
\hline & $\begin{array}{l}\text { Vehicle will decide if any help is } \\
\text { required based on the data analysis }\end{array}$ & $\mathbf{X}$ & $\mathbf{X}$ & & $\mathbf{X}$ \\
\hline & $\begin{array}{l}\text { Vehicle will confirm if the person has } \\
\text { authorization to use that vehicle }\end{array}$ & & & $\mathbf{X}$ & \\
\hline \multirow{5}{*}{ 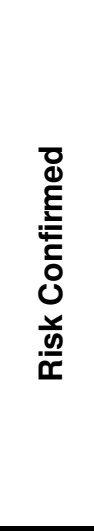 } & $\begin{array}{l}\text { System will inform the police or any } \\
\text { private security company. }\end{array}$ & $\mathbf{X}$ & & & \\
\hline & $\begin{array}{l}\text { System will inform the pre-set contact } \\
\text { through the platform cellular app. }\end{array}$ & $\mathbf{X}$ & $\mathbf{X}$ & $\mathbf{X}$ & $\mathbf{X}$ \\
\hline & $\begin{array}{l}\text { Vehicle will connect with the city } \\
\text { security cameras to monitor the } \\
\text { vehicle and support police actions. }\end{array}$ & $\mathbf{X}$ & $\mathbf{X}$ & & $\mathbf{X}$ \\
\hline & $\begin{array}{l}\text { Vehicle will connect the closest police } \\
\text { station to reduce the timing for the } \\
\text { action. }\end{array}$ & $\mathbf{x}$ & $\mathbf{X}$ & & $\mathbf{X}$ \\
\hline & System stops the vehicle & & $\mathrm{X}$ & $\mathbf{x}$ & \\
\hline \multirow{3}{*}{ 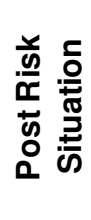 } & $\begin{array}{l}\text { System will provide the data to help } \\
\text { identification the thief }\end{array}$ & $\mathbf{x}$ & $\mathbf{X}$ & & $\mathbf{X}$ \\
\hline & $\begin{array}{l}\text { System will provide the vehicle } \\
\text { localization }\end{array}$ & $\mathbf{X}$ & $\mathbf{X}$ & & $\mathbf{X}$ \\
\hline & Police actions improvement & $\bar{X}$ & $\mathbf{X}$ & $\mathbf{X}$ & $\bar{X}$ \\
\hline
\end{tabular}

Elaborated by the authors 
Figure 2. Operating Mode on an Express Kidnapping

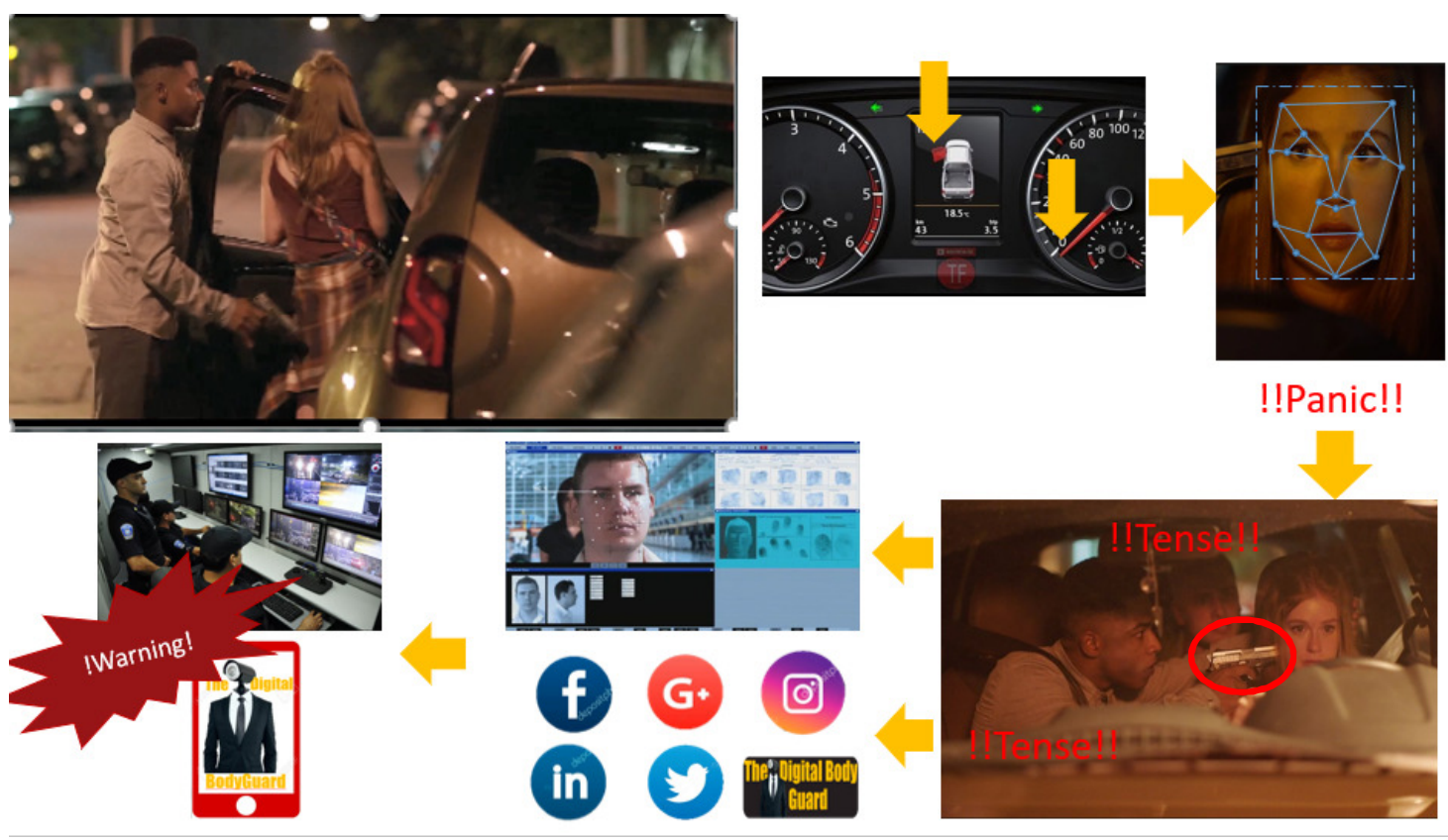

Elaborated by the authors

Images extracted from [11]

\section{CONCLUSION}

Security is a key element for individuals fulfill their basic needs and it is even more important in Brazil. A Digital Vehicle Security Platform is a way to use technology to improve the people's secure condition in the near future, by extending the usage of existing technologies to the automotive industry and it will open the door for a wide area to be explored with the connected vehicles in the smart cities.

\section{REFERENCES}

${ }^{1}$ MCLEOD, Saul. Maslow's Hierarchy of Needs. 2020. Available at: https://www.simplypsychology.org/maslow.html. Accessed on: 6 Aug. 2020.

2 SBCOACHING. Pirâmide de Maslow: O que é, Conceito e Definição. Available at: https://www.sbcoaching.com.br/blog/piramide-de-maslow/. Accessed on: 20 Jan. 2020.

3JEWELL, Elizabeth J. (ed.). Oxford American Desk Dictionary and Thesaurus. New York: Oxford University Press, 2002

${ }^{4} \mathrm{AMÂNCIO}$, Thiago. Brasil tem 1 roubo ou furto de veículo a cada minuto, Rio Lidera o Ranking. Available at: 